\title{
Improving Class 5 Student Learning Outcomes Theme 4 Sub-theme 2 Using the Discovery Learning Model
}

\section{Nanik Widayanti}

SD Negeri 2 Tanjungharjo

nanikn2k@gmail.com

\section{Article History}

accepted $14 / 11 / 2020$

\begin{abstract}
This study aims to improve the learning outcomes of grade 5 students using. The research conducted was Classroom Action Research (CAR) which was conducted in three cycles. Each cycle consists of four stages, namely planning, implementing, observing and reflecting. Each meeting is carried out an evaluation in the form of a written test to determine the development of students. In the first cycle, the students who completed the evaluation were $60 \%$. In cycle II students who completed after evaluating were $80 \%$. In the third cycle, students who completed after evaluating were $87.5 \%$. These results indicate that the Discovery Learning learning model can improve student learning outcomes, especially Theme 4 Subtema 2 Class $V$ at SDN 2 Tanjungharjo.
\end{abstract}

Keywords: learning outcomes, discovery learning, theme 4

\section{Abstrak}

Penelitian ini bertujuan untuk meningkatkan hasil belajar peserta didik siswa kelas 5 menggunakan. Penelitian yang dilakukan adalah Penelitian Tindakan Kelas (PTK) yang dilakukan sebanyak tiga siklus. Setiap siklus terdiri dari empat tahapan yaitu perencanaan, pelaksanaan, observasi dan refleksi. Setiap pertemuan dilakukan evaluasi berupa tes tertulis untuk mengetahui perkembangan peserta didik. Pada siklus I peserta didik yang tuntas setelah mengerjakan evaluasi sebesar $60 \%$. Pada siklus II peserta didik yang tuntas setelah melaksanakan evaluasi sebesar $80 \%$. Pada siklus III peserta didik yang tuntas setelah melaksanakan evaluasi sebesar $87,5 \%$. Hasil ini menunjukan bahwa model pembelajaran Discovery Learning dapat meningkatkan hasil belajar peserta didik khususnya Tema 4 Subtema 2 Kelas V di SDN 2 Tanjungharjo.

Kata kunci: hasil belajar, discovery learning, tema 4

Social, Humanities, and Education Studies (SHEs): Conference Series https://jurnal.uns.ac.id/shes 


\section{PENDAHULUAN}

Peraturan Menteri Pendidikan Nasional (Permendiknas) tahun 2006 tentang Standar Isi (SI) dan Standar Kelulusan (SKL) merumuskan bahwa pendidikan Nasional didasarkan pada pancasila Undang - undang Dasar Negara Republik Indonesia Tahun 1945. Peraturan tersebut berfungsi mengembangkan kemampuan dan membentuk watak serta peradaban bansa yang bermartabat dalam rangka mencerdaskan kehidupan bangsa yang bertujuan untuk mengembangkan potensi siswa agar menjadi manusia yang beriman dan bertaqwa kepada Tuhan Yang Maha Esa, berakhlak mulia, sehat, berilmu, cakap, kreatif, mandiri, dan menjadi warga Negara yang demokratis. Hal tersebut sejalan dengan Undang - undang nomor 20 tahun 2003 tentang sistem Pendidikan Nasional bahwa : Pendidikan adalah usaha sadar bahwa terencana untuk mewujudkan suasana Belajar dan proses pembelajaran agar peserta didik secara aktif mengembangkan potensi dirinya untuk memiliki kekuatan emosional dan Sepiritual keagamaan, pengendalian diri, kepribadian, kecerdasan, akhlak mulia, serta keterampilan yang diperlakukan dirinya, masyarakat, bangsa dan Negara. Proses pembelajaran yang menarik danmemberikan kesan serta pengalaman secara langsung, sesuai dengan kehidupan dan kebutuhan aktual siswa ialah proses pembelajaran yang diharapkan saat ini. Kurikulum 2013 adalah sebuah kurikulum yang dikembangkan untuk meningkatkan kemampuan soft skills dan hard Skill yang berupa sikap, keterampilan, dan pengetahuan

Upaya untuk meningkatkan mutu pendidikan nasional yang terus menerus dilakukan oleh pemerintah maupun masyarakat, misalnya pengembangan kurikulum nasional dan lokal, peningkatan kompetensi guru, pengadaan media pembelajaran seperti buku dan alat pembelajaran, perbaikan sarana dan prasarana pendidikan di sekolah. Untuk itu penulis merasakan pengembangan pembelajaran perlu ditingkatkan baik dari segi perencanaan, penggunaan model, alat peraga maupun kemampuan guru dalam mengembangkan kurikulum serta kemampuan sikap percaya diri dan penguasaan konsep pembelajaran dengan subtema Gangguan Organ Peredaran Darah.

Pendidikan harus mampu melahirkan sumber daya manusia yang berkualitas dan tidak menjadi beban pembangunan masyarakat, yaitu sumber daya manusia yang menjadi sumber kekuatan bagi seluruh proses pembangunan dan kehidupan masyarakat. Sekolah meberikan peran yang sangat penting sebagai dasar pembentukan sumber daya manusia bermutu sehingga anak belajar untuk mengetahui dan membangun keahlian serta membangun karakteristik mereka sebagai bekal menuju kedewasaan. Pemilihan model pembelajaran yang ditetapkan dalam pembelajaran tematik terpadu pada kurikulum 2013 antara lain : project based learning, problem based learning, dan discovery learning dapat mengaktifkan siswa serta menyadarkan siswa bahwa muatan pelajaran tematik tidak selalu membosankan. Dilihat dari hasil ulangan harian, sebagian besar nilai Kelas $\mathrm{V}$ SDN 2 Tanjungharjo masih di bawah Kriteria Ketuntasan Minimal (KKM) yaitu 65.

Dari berbagai jenis model pembelajaran yang ada, peneliti memilih menerapkan model discovery learning. Discovery learning merupakan suatu model pemecahan masalah yang akan bermanfaat bagi anak didik dalam menghadapi kehidupannya di kemudian hari. Penerapan model discovery learning ini bertujuan agar siswa mampu memahami materi gangguan organ peredaran darah dengan sebaik mungkin dan pembelajaran lebih terasa bermakna, sehingga hasil belajar siswa pun akan meningkat. Karena model discovery learning ini dalam prosesnya menggunakan kegiatan dan pengalaman langsung sehingga akan lebih menarik perhatian anak didik dan memungkinkan pembentukan konsep-konsep 
abstrak yang mempunyai makna, serta kegiatannya pun lebih realistis (Ilahi, 2012). Kegiatan penemuan yang dilakukan oleh manusia itu sendiri dan dilakukan secara aktif akan memberikan hasil yang paling baik, serta akan lebih bermakna bagi dirinya sendiri (Bruner dalam Sujana, 2014). Model discovery learning pun banyak memberikan kesempatan bagi para anak didik untuk terlibat langsung dalam kegiatan belajar, kegiatan seperti itu akan lebih membangkitkan motivasi belajar, karena disesuaikan dengan minat dan kebutuhan mereka sendiri. Model discovery learning ini menitikberatkan pada kemampuan mental dan fisik para anak didik yang akan memperkuat semangat dan konsentrasi mereka dalam melakukan kegiatan pembelajaran.

Adapun tahapan model discovery learning, terdiri dari observasi untuk menemukan masalah, merumuskan masalah, mengajukan hipotesis, merencanakan pemecahan masalah melalui percobaan atau cara lain, melaksanakan pengamatan dan pengumpulan data, analisis data, dan menarik kesimpulan atas percobaan yang telah dilakukan atau penemuan. Jika siswa dilibatkan secara terus-menerus dalam pembelajaran penemuan, maka siswa akan lebih memahami dan mampu mengembangkan aspek kognitif yang dimilikinya (Suryosubroto, 2009). Melalui model discovery learning siswa menjadi lebih dekat dengan apa yang menjadi sumber belajarnya, rasa percaya diri siswa akan meningkat karena dia merasa apa yang telah dipahaminya ditemukan oleh dirinya sendiri, kerjasama dengan temannya pun akan meningkat, serta tentunya menambah pengalaman siswa (Putrayasa, 2014).

\section{METODE}

Penelitian ini adalah penelitian tindakan kelas (Classroom Action Research) dengan menerapkan model pembelajaran Discovery Leraning. Menurut Kurt Lewin dalam Kusnandar (2011: 42) penelitian tindakan kelas ini terdiri dari empat tahapan dasar yaitu perencanaan (planning), pelaksanaan (acting), pengamatan (observing) dan refleksi (reflecting). Analisis penelitian ini adalah analisis deskriptif kuantitafif kualitatif dimana dalam penelitian ini selain penyajian hasil berupa data maupun angka peneliti juga menentukan bagaimana cara pengolahan hasil penelitian yakni dengan membuat analisisnya dengan menerapkan model penelitian Discovery Learning. Penelitian ini dilaksanakan pada peserta didik kelas V SD Negeri 2 Tanjungharjo Tahun Pelajaran 2020/2021 selama tiga siklus secara daring menggunakan aplikasi Google meet. Siklus I dilaksanakan pada tanggal 28 Oktober- 03 November 20202020. Siklus II dilaksanakan pada tanggal 04-10 November 2020. Siklus III dilaksanakan pada tanggal 17-23 November 2020. Teknik pengumpulan data yang dilakukan dengan observasi dan tes.

\section{HASIL DAN PEMBAHASAN}

Pada siklus I pembelajaran dilaksanakan dengan satu kali pertemuan dan mengadakan evaluasi disetiap akhir pembelajaran. Hal tersebut dilakukan untuk mengetahui perkembangan hasil belajar peserta didik. Siklus I membahas materi tema 4 subtema 2 tentang arti makna pantun dan gangguan peredaran darah. Pembelajaran dengan model discovery learning dilakukan dengan 6 langkah yaitu pemberian rangsangan, identifikasi masalah,pengumpulan data, pengolahan data,pembuktian,dan menarik kesimpulan. Berikut adalah hasil peserta didik siklus I 
Tabel 1. Hasil Belajar Peserta Didik Siklus I

\begin{tabular}{llcc}
\hline NO & Rentang Nilai & \multicolumn{2}{l}{ Frekuensi Siswa } \\
\cline { 3 - 4 } & & - & Tidak Tuntas \\
\hline 1. & $90-100$ & - & - \\
\hline 2. & $80-89$ & 24 & - \\
\hline 3. & $70-79$ & - & - \\
\hline 4. & $59-69$ & 24 & 16 \\
\hline & Jumlah & $60 \%$ & $40 \%$
\end{tabular}

Dari tabel diatas terlihat bahwa ada 24 siswa yang mendapatkan nilai 65 keatas atau sebesar $60 \%$ dan 16 siswa atau $40 \%$ memperoleh nilai kurang dari 65 . Nilai terendah berada di nilai 60 dan nilai tertinggi mengalamai peningkatan yaitu 77 . Jika dibandingkan dengan pembelajaran awal, hasil belajar siswa pada siklus I mengalami kenaikan yang signifikan. Pada awal pembelajaran yang mendapat nilai di atas 65 sebesar 14 siswa (40 \%) dan yang lainnya sejumlah siswa $24(60 \%)$ mendapat nilai di bawah KKM.

Berdasarkan refleksi pada siklus I maka diputuskan untuk melanjutkan ke siklus II dikarenakan belum mencapai ketuntasan klasikal yang diharapkan. Siklus II membahas materi makna pantun dan gangguan organ peredaran darah. Pembelajaran dengan model Discovery Learning dilaksanakan dengan 6 langkah secara berurutan seperti siklus I. Berikut ini adalah hasil belajar peserta didik pada siklus II yang bisa dilihat pada tabel berikut

Tabel 2. Hasil Belajar Peserta Didik Siklus II

\begin{tabular}{llcc}
\hline \multirow{2}{*}{ NO } & Rentang Nilai & \multicolumn{2}{l}{ Frekuensi Siswa } \\
\cline { 3 - 4 } & & 1 & Tidak Tuntas \\
\hline 1. & $90-100$ & 15 & - \\
\hline 2. & $80-89$ & 14 & - \\
\hline 3. & $70-79$ & - & 10 \\
\hline 4. & $59-69$ & 30 & 10 \\
\hline & Jumlah & $80 \%$ & $20 \%$
\end{tabular}

Dari tabel diatas terlihat bahwa ada 30 siswa yang mendapatkan nilai 65 keatas atau sebesar $80 \%$ dan 10 siswa atau $20 \%$ memperoleh nilai kurang dari 65 . Nilai terendah berada di nilai 60 dan nilai tertinggi mengalamai peningkatan yaitu 90 . Jika dibandingkan dengan pembelajaran siklus I, hasil belajar siswa pada siklus II mengalami kenaikan yang signifikan.

Setelah melakukan refleksi pada siklus II, maka diputuskan untuk melanjutkan pada siklus III. Hal ini dilakukan agar mengetahui sejauh mana penerapan pembelajaran Discovery Learning tidak hanya meningkatkan tetapi juga mempertahankan hasil belajar peserta didik. Pada siklus III materi yang diajarkan amanat pantun dan faktor penyebab gangguan peredaran darah, peserta didik mengerjakan proyek sebuah pamflet berisi informasi tentang simbiosis. Hasil belajar peserta didik dapat dilihat pada tabel berikut 
SHEs: Conference Series 3 (3) (2020) 673-677

Tabel 3. Hasil Belajar Peserta Didik Siklus II

\begin{tabular}{llcc}
\hline NO & Rentang Nilai & \multicolumn{2}{l}{ Frekuensi Siswa } \\
\cline { 3 - 4 } & & 1 & Tuntas \\
\hline 1. & $90-100$ & 15 & - \\
\hline 2. & $80-89$ & 20 & - \\
\hline 3. & $70-79$ & - & 4 \\
\hline 4. & $59-69$ & 36 & 4 \\
\hline & Jumlah & $90 \%$ & $10 \%$
\end{tabular}

Dari tabel diatas terlihat bahwa ada 36 siswa yang mendapatkan nilai 65 keatas atau sebesar $90 \%$ dan 4 siswa atau 10\% memperoleh nilai kurang dari 65 . Nilai terendah berada di nilai 60 dan nilai tertinggi mengalamai peningkatan yaitu 90 . Jika dibandingkan dengan pembelajaran siklus II, hasil belajar siswa pada siklus III mengalami kenaikan yang signifikan. Dari tiga siklus yang sudah dilaksanakan selama 3 pertemuan dapat dipastikan bahwa model pembelajaran discovery learning dapat meningkatkan hasil belajar peserta didik Tema 4 Subtema 2 Kelas V di SD Negeri 2 Tanjungharjo.

\section{SIMPULAN}

Berdasarkan temuan dan analisis yang diperoleh dalam pelaksanaan pembelajaran daring Tema 4 Subtema 2 Penerapan model pembelajaran Discovery Learning dapat meningkatkan hasil belajar peserta didik Kelas $\mathrm{V}$ Tema 4 Subtema 2 materi gangguan organ peredaran darah. Peningkatan yang terjadi karena adanya kesan pembelajaran yang mendalam dari peserta didik tehadap materi yang diajarkan. Peserta didik akan selalu teringat akan materi yang diajarkan dikarenakan mereka menemukan dan membangun sendiri pengetahuan mereka. Berdasarkan penelitian yang telah dilaksanakan salah satu model pembelajaran yang harus dikuasai guru adalah Discovery Learning karena model ini sangat cocok digunakan dalam keadaan pandemi seperti ini, apalagi dalam kondisi belajar dari rumah.

\section{DAFTAR PUSTAKA}

Kusnandar. (2010). Langkah Mudah Penelitian Tindakan Kelas Sebagai Pengembangan Profesi Guru. Jakarta : Raja Grafindo Persada.

Kusnandar. (2011). Langkah Mudah Penelitian Tindakan Kelas Sebagai Pengembang

Profesi Guru. Jakarta: PT Raja Grafindo Persada

Kementrian Pendidikan dan Kebudayaan. (2013). Materi Pelatihan Guru Implementasi Kurikulum 2013. Kementrian Pendidikan dan Kebudayaan. Jakarta

Miyarso, E. (2019). Perancangan Pembelajaran Inovatif. Jakarta: Kemdikbud.

Putrayasa, I., Syahruddin, H. \& Margunayasa, I. (2014). Pengaruh Model Pembelajaran Discovery Learning Dan Minat Belajar Terhadap Hasil Belajar Ipa Siswa, II(1), hlm 111

Suryosubroto. (2009). Proses Belajar Mengajar di Sekolah. Jakarta: Rhineka Cipta 